\title{
Are there income effects on global willingness to pay for biodiversity conservation?
}

Jette Bredahl Jacobsen

Nick Hanley

Stirling Economics Discussion Paper 2008-03

March 2008

Online at http://www.economics.stir.ac.uk 


\title{
Are there income effects on global willingness to pay
}

\section{for biodiversity conservation?}

\author{
Jette Bredahl Jacobsen and Nick Hanley
}

March 2008.

\begin{abstract}
This paper is concerned with the empirical relationship between biodiversity conservation values and income. We use random effects panel models to examine the effects of income, and then GDP per capita, on willingness to pay for habitat and biodiversity conservation. In a meta-analysis, 145 Willingness To Pay estimates for biodiversity conservation where existence value plays a major role were collected from 46 contingent valuation studies across six continents. Other effects included in the meta-analysis were the study year; habitat type; continent; scope as presented to respondents; whether WTP bids were for preventing a deterioration or gaining an improvement in conservation, whether a specific species or specific habitat was protected; whether the questionnaire used a dichotomous choice or an open-ended format; distribution format; and the choice of payment vehicle. GDP per capita seemed to perform as well as an explanatory variable as respondent's mean stated income, indicating that it is wealth in society as a whole which determines variations in WTP. Our main conclusion is that the demand for biodiversity conservation rises with a nation's wealth, but the income elasticity of demand is less than one.
\end{abstract}

JEL Codes: Q2, H4, D6

Key-words: meta-analysis, income effects, contingent valuation, existence values, Environmental Kuznets Curve. 


\section{Introduction}

This paper is concerned with the relationship between Willingness to Pay (WTP) for biodiversity conservation and income. By "biodiversity conservation", we mean actions which protect or improve either habitats or species. Two contrasting definitions of income are used: first, average household income (or, in a minority of cases, average personal income) in the sample from which the WTP estimates are drawn: and second, GDP per capita for the country from which the sample is drawn. Some 46 Contingent Valuation studies from 6 continents form the data base for the paper. We focus on studies which have tried to estimate non-use values for biodiversity conservation. Our main research question is this: is there empirical evidence that willingness to pay for biodiversity conservation increases with income? The importance of this question relates to current debates over the existence of an "Environmental Kuznets Curve" for environmental quality in general, and for biodiversity in particular (Deacon and Norman, 2006; McPherson and Nieswiadomy, 2005). It also relates to an older literature dating to Krutilla and Fisher (1975), on how preservation values for natural environments can be expected to evolve over time, considering that depletion of many natural resources is irreversible; and to debates over the distributional effects of environmental policy (Kristrom and Riera, 1996; Ebert, 2003).

\section{Determinants of the demand for environmental quality}

In 1955 Kuznets suggested an inverted U-shaped relationship between an indicator of income inequality and the level of household income (Kuznets, 1955). A relationship similar to the Kuznets curve has been found between national income (GDP per capita) and a number of pollutants, and this relationship is often referred to as the Environmental Kuznets Curve (EKC) (Grossman and Krueger, 1995). The relationship implies that as economic growth occurs, pollution increases up to 
a certain income level. After this "turning point", pollution begins to decrease. Suggested reasons for this empirical regularity are structural economic change, technological development, and - what is key to this paper - an increasing demand for environmental quality and environmental regulation as real per capita incomes increase (Barbier 1997). Empirical evidence both in support of and in contradiction of a U-shape relationship between pollution and income can be found in the literature (Deacon and Norman, 2006). Barbier (1997) argues that most empirical studies show that a very high level of income per capita is needed before environmental quality begins to increase, implying that most countries have not yet reached a turning point, even if it exists for some pollutants. Of direct relevance to this paper is the search for EKC-type relationships for measures of biodiversity. McPherson and Nieswiadomy (2005) investigated the relationship between species counts for threatened mammal and bird species in 113 countries and real per capita income, finding indications of an $\mathrm{EKC}$ shape in both cases. In other words, species numbers initially decline as incomes rise, but then start to rise again.

As noted above, an important "driver" in EKC theories is the effect of income growth on the demand for environmental quality (see, for example, Bruvoll et al., 2003). It has long been argued that environmental quality is a luxury good, with an income elasticity of demand greater than one (Kriström and Riera, 1996). If this is so, then demand for environmental goods, manifested either as consumers buying greener products, or demanding tougher environmental legislation, will grow disproportionately quickly as incomes rise. However, both Kriström and Riera (1996) and Hökby and Söderqvist (2003) question this assumption.

An important distinction in this literature is between the income elasticity of demand and the income elasticity of WTP. Most goods valued using the kind of stated preference methods upon which Kriström and Riera base their conclusions are public goods which are in fixed (rationed) 
quantities from the perspective of the individual, so that the individual cannot continuously vary the quantity of goods he or she demands (an exception is recreational trips to an outdoor recreational resource such as a national park). Stated preference studies offer individuals the chance to bid on a very limited range of supply options for the public good. Therefore the construction of a conventional income elasticity of demand measure is problematic. A more suitable measure of income responsiveness is the income elasticity of WTP, $\varepsilon_{\mathrm{W}}$, which can be defined as:

$$
\varepsilon_{w}=\frac{y}{W T P} \frac{\partial W}{\partial y}=\frac{\partial(\ln W)}{\partial(\ln y)}
$$

where $y$ is income and $W$ is a "bid function" for WTP (Flores and Carson, 1997; Hökby and Söderqvist, 2003). Therefore we cannot use a distinction between luxury good and normal goods as discussed above. However, it is possible to quantify the distributional pattern of WTP: when $\varepsilon_{\mathrm{w}}<1$ the environmental good is said to be distributed regressively, and distributed progressively if $\varepsilon_{\mathrm{w}}>1$. If $\varepsilon_{\mathrm{w}}<1$, then projects which promote environmental conservation have the possibility of benefiting poorer households more than rich households, in the sense that the proportion of WTP to income is decreasing as incomes rise - an environmental good for which $\varepsilon_{\mathrm{w}}<1$ has proportionately higher benefits to poor groups than to rich groups (see Ebert, 2003).

It is also useful to distinguish between the kinds of environmental goods for which people are asked to state a WTP amount. Use values dominate total economic value for many environmental goods, such as clean water, better air quality and reduced risks to health, and many meta-analyses of stated and revealed preference values are focussed on such goods. In this paper however we will focus on non-use values for biodiversity and habitats. Non-use values for biodiversity and habitats might be argued to be more progressively distributed than use values. The income elasticity of WTP for goods the benefits of which are dominated by non-use values may well be different than the income 
elasticity of WTP for environmental goods for which a change in supply has more immediate or more obvious personal consequences than losses in biodiversity. The main aim with the present study is thus to investigate the income elasticity of WTP for an environmental good - biodiversity conservation - where non-use values are believed (by those conducting the primary studies on which our meta-analysis is based) to play a major role.

Environmental Kuznets Curve studies focus on average incomes across a whole society as determinants of environmental quality, by using explanatory variables such as real GDP per capita. In contrast, stated preference studies use measures of personal or household income as a determinant of WTP. Sometimes a statistically significant effect is found between individual or household income and WTP (e.g. Bergstrom et al.1985; Brouwer and Bateman, 2001; Macmillan et al.2001; Veisten et al. 2004), whilst sometimes no significant effect is found (Macmillan et al.2001; White et al.1997). Accordingly, in this study we investigate both the effects of wealth in society, measured by GDP per capita, and household (or personal) income on WTP for biodiversity and habitat conservation. As we note later, self-reported income in Contingent Valuation studies is in any case a problematic choice of explanatory variable when studying the causes of variations in WTP.

Clearly, many factors other than income or wealth can affect WTP. Most obviously, studies find different WTP amounts because they value different goods. For studies looking at wildlife and habitat conservation, the specific habitat or species being considered, whether it is unique, and whether it is known to the public is important (Christie et al, 2006). Moreover, whether a charismatic or a rare species is to be preserved can matter (Metrick and Weitzman, 1994, Hanley et al. 2003), along with the size of prospective change in the habitat or species. Other reasons for variation in WTP are found in the valuation methods being applied. Focusing on differences in 
stated preference methods, differences are found between Contingent Valuation (CV) and choice experiments (Riera et al. 2007, Boxall et al. 1996, Hanley et al. 1998a, Hanley et al. 1998b, Lehtonen et al. 2003) and between the different formats in CV - for example, between dichotomous choice, open ended or payment card designs (Johnson et al. 1990; Reaves et al., 1999; Welsh and Poe, 1998). Finally, differences in WTP might be caused by non-income differences in the population of beneficiaries being studied (e.g. Boiesen et al., 2005; León, 1996; Turpie, 2003; Lindhjem, 2007), for example in terms of rural versus urban location.

\section{Meta-studies in environmental valuation}

Meta-analysis started as a tool in medical research for analysing knowledge accumulated from many different studies (Hunter and Schmidt, 2004). Later, its use extended to other areas like economics (Pang et al. 1999) and more specifically environmental economics (van den Berg, 1997, Bal et al. 2002). One aim of meta-analysis can be to analyse consistency across studies, controlling for factors (such as income) which may be thought a priori to drive variations in outcomes (such as WTP estimates). One of the first applications within environmental economics was Smith and Kaoru's (1990) analysis of travel cost estimates of recreation values. Other applications are analyses of values for rare and endangered species (Loomis and White, 1996), for coral reefs (Brander et al., 2007), for groundwater protection (Poe et al., 2000), for wetlands (Brander et al., 2006, Brouwer et al. 1999, Woodward \& Wui, 2001), for forests (Lindhjem, 2007) and forest recreation (Bateman and Jones, 2003). Smith and Osborne (1996) use the method for a more methodological purpose, namely as a test for scope effects. Income effects on willingness to pay are analysed in some of the above-mentioned studies. Brander et al (2006) find GDP per capita to be positively and significantly correlated with WTP and Poe et al. (2007) find a positive and significant income effect. Schläpfer (2006) takes a slightly different approach, and investigates what determines 
whether income is statistically significant within a study. He does that using a logit model to test for the presence of a significant income effect. In $36 \%$ of the studied cases, income is significant. Interestingly for this paper, whether a study was classified by the author as eliciting non-use (passive use) values compared with use values did not have a significant influence on the presence of an income effect.

An important step in a meta-study is the development of a protocol for including or excluding studies: for example, restrictions can be imposed for reasons of geography, valuation method applied, topic, or quality of the study. Meta-analyses in environmental economics are normally restricted both geographically and with respect to topic, partly due to a desire to make use of results for benefit transfer. Exceptions are studies with a focus on methodological differences. In our study we do not restrict the studies to be included on geographical grounds: on the contrary, we want to include as wide a spatial spectrum as possible in order to analyse income effects across countries. Restricting the analysis to specific habitats also makes little sense, since habitat variation is so great at the global level, and therefore we include studies for any habitat. Instead we restrict the studies to those which focus on estimating non-use values for biodiversity and habitat conservation, since our purpose is to test for a relationship between willingness to pay and income which would be consistent with the existence of an EKC for biodiversity conservation. Only a few previous metastudies have focused on such non-use values (e.g. Lindhjem, 2007). Furthermore, other studies focusing on the existence of an EKC for biodiversity analyse the causality going from income to biodiversity per se (e.g. McPherson and Nieswiadomy, 2005), whereas we look at the effects of rising income on WTP for biodiversity.

\section{Collection of data}


This meta-analysis is based on 46 contingent valuation studies (see Appendix 1) which report 145 relevant WTP estimates. Information is taken from published papers, papers in the process of publishing or reports which are at a publishable level. Most of the papers can be found on Web of Science. Criteria for selection of studies were focus on existence value and access to income measures. All the studies value nature goods where the researchers claim that existence value plays a major role. As existence and use value are seldom separable, we do not attempt to exclude estimates of use value. However, studies which focus on use values alone or studies carried out solely on respondents visiting an area are excluded. Information regarding respondent's income was also a requirement for inclusion, and lack of income data was the main reason for exclusion of many studies. Where sufficient information could not be found in the paper, the lead author was contacted (some studies have been excluded as the authors could not be contacted). Where income data was missing and the paper states that the sample was representative for the population, national statistics have been used instead. This is the case for 8 studies (15 estimates), one from Australia and 7 from the USA. Otherwise, sample income information has been collected from authors. A measure of gross domestic product per capita (GDP) is included for each country in the year for which the original study was undertaken. Data on GDP was obtained from IMF (2007a). Most studies value several supply levels of the same good or use different estimation procedures to come up with a range of value estimates. We have decided to use all the WTP estimates available in order not to hide eventual estimation differences by averaging them. Multiple estimates from a single study are treated as a panel. The studies included were carried out all over the world, although with a focus on developed countries. It has been difficult to find valuation studies from poor countries which focus on existence values, although there are a few. Table 1 shows an overview of the estimates.

[Insert Table 1 about here] 
Some of the variation in the willingness to pay data may be caused by differences in the way the good was presented to respondents. In order to analyse, this we included two characterisation variables. One variable indicates whether the project in question preserves habitat or species, i.e. "saves" objects which would otherwise disappear, or whether the scenario involved an improvement in preservation conditions. The other variable tries to capture the scope of the conservation issue as presented to respondents. It takes the value zero ( a "part value") if it was explained to respondents that a given project is a part of the protection scheme for nature in a country; and the level of one (a "whole value") if the protection is taken to cover all of a policy (the establishment of a national park not considering substitutes, the protection of a species across a whole country, etc.). Notice that what is considered part or whole is determined by what was presented to respondents, not what is a correct biological distinction. Sometimes external scope tests are carried out in a study, but if the substitutes or relative importance of the good is not mentioned to the respondents, the variable scope takes the same value. The reason for doing this is that the magnitude of goods which consist largely of existence value will often be difficult for people to have a good grasp of. Thus the valuation context constructed for them is often seen as very important for their understanding thereof (see e.g. Bateman \& Mawby 2004, Mitchell \& Carson, 1989). All monetary terms are converted to 2006 US \$, by first inflating by the national consumer price index and then using purchasing-power-parity (PPP) to convert to values to US \$. Inflation and PPP estimates are from the International Monetary Fund (IMF 2007a).

[Insert Table 2 about here] 
Table 2 summarises the variables used in the model. Educational achievement would have been an obvious variable to include, but as it is not reported on a common scale this was not possible. The variable study year may capture unobserved development in the contingent valuation method as well as in the societies studied. In some of the analyses fewer than 145 estimates are used due to missing information. Income is reported as household income in 124 cases and personal income in 17 cases, with 3 cases being unspecified. WTP is reported in per household terms in 110 cases, per person terms in 33 cases, and one case is unspecified. Personal income and personal WTP statements are not converted to the corresponding household measures as household size is generally not reported for the studies related to individual payment. Where personal income measure is used, the corresponding payment is always personal and will therefore not result in interpretation problems assuming respondents have interpreted the right context, and there is no income pooling (cf. Munro 2005). For some studies personal payment and only household income is reported. These studies are excluded in the analyses where income is modelled, whereas all studies reporting personal payment are excluded in models based on GDP.

\section{Analysis and results}

Figure 1 shows WTP for biodiversity conservation as a function of income depending on whether income was measured per person or per household. One outlier is observed (a mean WTP of over \$700). According to the original study (León, 1996) this estimate's reliability is questionable and consequently it was excluded from the analyses below. Another potential outlier is seen with a WTP of $\$ 316$. This observation is from a study regarding preservation of both a number of species and a specific species (Jakobsson and Dragun, 2001), and the difference in the estimates in the original study seems to be caused by the specification of the good. Therefore this potential outlier is not removed. 
[Insert figure 1 about here]

The analytical starting point was an ordinary least squares linear regression with use of the HuberWhite technique to correct for heteroscedasticity and serial correlation (see the procedure described in Greene, 2002). As most of the reported studies report more than one estimate, this ultiple reporting could be used as a stratification process. Thus we used the process described by Rosenberger and Loomis (2000) to test for panel structures in the data, in that we specify:

$$
W T P_{i j}=\alpha+\sum_{i=1}^{n} \beta_{i} x_{i j}+\mu_{i j}+\varepsilon_{i}
$$

where $\mathrm{WTP}_{i j}$ is $\mathrm{WTP}$ for the $i$ 'th observation in the $j$ 'th strata (here study), $\alpha$ is a constant, $x_{i j}$ is a vector of explanatory variables, with a panel effect $\mu_{i j}$ and an error $\varepsilon_{i} \sim \mathrm{N}\left(0, \sigma_{\varepsilon}^{2}\right)$. A Breusch and Pagan's Lagrange multiplier test was performed to test whether $\mu_{i j}=0$. For a random effects model with income as the only explanatory variable, this test showed that a model with equal effects was rejected, and that a panel estimation was therefore appropriate $\left(\chi^{2}=42.42, p=0.000\right.$ with $\mathrm{N}=128$ and $\mathrm{j}=42$ ). The Breusch and Pagan Lagrange multiplier test and subsequently performed on all the models presented below and gave the same conclusions, namely that a random effects panel model was the best fit to the data, compared to a simple pooled model. A random effect models was chosen instead of a fixed effects model due to no a priori expectations of the fixed study effect being correlated with other study characteristics. Furthermore, for the GDP version of the models a fixed effects specification is not possible, since GDP is not separable from the fixed study effect.

[Insert Table 3 about here] 
Looking at Figure 1, no obvious functional form is apparent for the relationship between income and WTP. Several functional forms were tried in the random effects panel models - a linear, a semi$\log$, a quadratic and a double log version. Using Wald tests, the best specification was obtained by the $\log$ models $\left(\chi^{2}=7.73\right.$ with $p>\chi^{2}=0.0054$ for the semi-log model and $p>\chi^{2}=0.0076$ for the double- $\log$ model vs. $p>\chi^{2}=0.16$ for the linear and $p>\chi^{2}=0.60$ for the quadratic). A similar plot of WTP against GDP per capita does also not show an immediate apparent relationship, and again log models performed best. Income and GDP per capita are highly correlated (0.68), and therefore they were specified as explanatory variables in separate models (that is, income and GDP per capita could not be included in the same model, nor was it desirable to do so, since we are interested in comparing the responsiveness of WTP to these different measures of resources).

Four simple random effect models of the relationship between income or GDP alone with WTP are reported below. The specifications are:

Model 1: Random effects model of WTP, $\beta_{1}$ is the parameter for $\ln$ (income per year)

Model 2: Random effects model of $\ln (\mathrm{WTP}), \beta_{1}$ is the parameter for $\ln ($ income per year)

Model 3: Random effects model of WTP, $\beta_{1}$ is the parameter for $\ln (\mathrm{GDP})$ per capita per year Model 4: Random effects model of $\ln (\mathrm{WTP}), \beta_{1}$ is the parameter for $\ln (\mathrm{GDP}$ per capita per year)

Results are shown in Table 3. It can be seen that both income and GDP per capita are significantly and positively related to willingness to pay for biodiversity conservation. The single-log models perform slightly better for both income and GDP if evaluated based on the $\mathrm{R}^{2}$ measures. However, since the studies from which the database is constructed vary in many respects other than in the income and WTP values reported, models were then estimated with all the meta-analytic variables 
shown in Table 2 included. Results are shown in Table 4, this time focussing on just the semi-log versions, which fitted best. In Table 4a, all variables described in Table 2 are used in the estimation.

[Insert Table 4 about here]

From Table 4a it can be seen that neither income nor GDP per capita is significant in these fuller specifications. Interestingly, not many of the study design variables are able to explain the variation in WTP. The only significant variables are whether the payment scenario concerned a specific habitat, and whether dichotomous choice or open ended format was used. The correlation between income and the other variables is also shown in the table. Apart from the obvious fact that continent and GDP per capita correlates somewhat, it is seen that the highest correlations are found between format and both GDP per capita and income, between study year and income and between donation and GDP. Generally the correlations are not very high. When a non-panel model was estimated, correlations were much higher - often between $|0.8|$ and $|1|^{1}$.

Since Table 4a shows that most of the study design variables were insignificant determinants of WTP for biodiversity conservation, we re-estimated the model for income and for per capita GDP including only those study design variables which were significant at $95 \%$ from Table $4 \mathrm{a}$, that is, specific habitat and method. Results are shown in Table 4b. These show that the parameters on income and on GDP are now significant at the 90\% level, although still not significant at the $95 \%$ level. Based on a Hausman test, we could not reject the null hypothesis of equivalence between the parameters on income and GDP from the income/GDP only models shown in Table 3, and those from the reduced form models shown in Table $4 \mathrm{~b}$. We can also see that the size of the parameters

\footnotetext{
${ }^{1}$ We also tried to estimate a model where WTP was averaged for studies originating from the same study as e.g. also Lindhjem (2007) does. Though $\mathrm{R}^{2}$ increases to 0.26 and 0.31 for the models based on income and GDP per capita respectively, a panel structure could still not be rejected (results not shown). Furthermore, these models have a very high correlation between the variables included.
} 
on income and per capita GDP comparing Tables 3 and 4b is very similar (eg 29.12 in Table 3 for per capita GDP, and 29.11 in Table 4b). The main conclusion is thus that income and GDP are significantly related to willingness to pay for biodiversity conservation: rising income leads to rising WTP.

Finally, it is interesting to investigate what is driving the internal significance or otherwise of the income variable in the studies which form our dataset ${ }^{2} .56$ of the 145 data points reported internal significance of income as an explanatory factor for WTP, whilst 39 reported insignificant effects. Some 50 data points did not specify which of these was the case; however, often income is only reported if it shows significance in terms of impacts on WTP, so some of these observations may represent studies where income did not have a significant effect on WTP. Following Schlapfer (2006), we estimated a logit model of whether the internal income significance could be determined by any of the study design variables shown in Table 2. Results are shown in Table 5. Interestingly, both increasing income and increasing GDP levels caused lower likelihood of internal income significance. Whether a survey was concerned with protecting existing biodiversity or increasing biodiversity conservation (save) was also significant, as was use of a voluntary payment mechanism (donation) and whether a dichotomous choice or open-ended format was used (method). Focus on a specific species or habitat also had a significant effect, but only in the GDP version of the model.

[Insert Table 5 about here]

\section{Discussion}

The analysis presented above focuses on whether there is an income effect on WTP for biodiversity conservation where non-use values play a major role. Studies of WTP usually analyse the

\footnotetext{
${ }^{2}$ We thank one of the referees for this suggestion.
} 
relationship between income and WTP within a survey sample. In fact, only $39 \%$ of the studies used to form the database show that such a correlation was positive and significant. In this study the focus is on external tests of dependence across studies, contexts and societies, and we were able to find a positive relationship between income or GDP per capita and WTP for biodiversity conservation, although the detected strength of this relationship is not as great as might have been expected, nor is it estimated with high precision. This may be due to the high level of noise in the data, causing the significance and strength of inter-linkages to be dependent on the specific model used. We also find that GDP per capita is as good a predictor of WTP for biodiversity conservation as income. Income and GDP per capita are of course highly correlated ( +0.7 in our data). However, one can argue that irrespective of the empirical results, GDP per capita is a preferable variable to relate to WTP if one is interested in the effects of growing wealth on the demand for biodiversity conservation, which as we noted above, is one of the main theoretical drivers underlying the Environmental Kuznets Curve. This is for two reasons. First, household (personal) income figures from CV surveys are self-reported, and thus may be inaccurate in the sense of deliberate misstatement. Income reports are also typically only provided by respondents as a range (and thus are imprecise), but more importantly are poorly defined: do all CV respondents take the same view in calculating all their income sources before responding? Do all respondents take the same view about reporting pre- or post- tax incomes? Non-wage income and income for some household members may be under-reported or not reported al at all. In other words, income as a variable in a meta-analysis of CV studies is poorly defined. GDP per capita, in contrast, is well-defined and consistent across countries, yet still represents the essence of what income measures try to capture in CV models. Second, if we are trying to understand how the demand for environmental quality increases as countries get richer - a key underlying story in the EKC literature - then GDP per capita gives a wider picture of "available resources" or spending power for society than does household income, since it represents all sources of income within an economy. In relating findings 
to the EKC literature, the main finding is thus that within this data, rising GDP per capita increases WTP for biodiversity conservation, although the effects are not always strong.

Based on the results from the double-log models in Table 3 we find an income elasticity of WTP for biodiversity conservation to be +0.38 , both when using GDP per capita and household/personal income, indicating that WTP for biodiversity conservation is regressively distributed. As incomes rise, this means that the fraction of income that will be offered as a maximum payment for biodiversity conservation will fall (ie that $\partial(W T P / y) / \partial y<0)$. This is noteworthy, especially since the focus here is on existence values and not on use values, and indeed this is also how the respondents seems to have understood the $\mathrm{CV}$ questions asked in the studies from which our data is constructed. Thus the focus on non-use values does not seem to change the conclusions from Kriström \& Riera (1996) and Hökby \& Söderqvist (2003), that WTP income elasticities lie between 0 and 1 . Still the conclusion remains that the richer a country, a given rate of economic growth will translate into a larger absolute WTP for conservation than in a poorer country.

A critique of this study could be that it tries to cover goods that are too different to each other (for example, elephants in Sri Lanka versus wetlands in Norfolk, England). It is therefore very interesting that neither the continent nor the habitat-type variables (habitats: sea, habitat: wetlands, or habitat: open areas) seem to cause systematic changes in WTP according to the results shown in Table 4a. This might indicate that nature protection per se is what is valued in the individual CV studies, rather than the specific habitat in question. This could be due to a high level of warm glow or moral satisfaction being present in the WTP responses as indicated by the variable scope not being significant. However, the scope variable is difficult to construct across studies, and therefore is a weak criteria as used here. The small difference between habitats could also be an indication of respondents having a high willingness to trade-off different nature goods within the broad habitat 
categories used here. This last interpretation is supported by one study partly included in the database which compared WTP across several habitats (Jacobsen et al., 2006 \& Jacobsen \& Thorsen, 2008) and found that respondents were very willing to substitute (trade-off) between them. An alternative view is that the way in which habitats have been characterised in this meta-analysis is too crude. For example, a boreal and a tropical forest are very dissimilar goods, though we group them together here.

Another grouping of the goods valued used was whether a study focused on specific species or habitat protection. Surprisingly the protection of species is not a significant determinant of WTP, whereas protection of habitats is (and it is positive). We could also have expected that the moral issues of saving species and habitats in decline could cause the variable save to be significant, but this is not the case. In the analysis on internal income effects (Table 5) save does cause income effects to be less significant, probably indicating a moral issue with paying. Finally we find that dichotomous choice questions tend to give higher WTP values than open-ended formats. This has been noted by other authors such as Bateman et al. (1995) and Johnson et al. (1990). Again it is questionable if a more detailed classification of estimation procedures and re-grouping of discrete choice formats, into e.g. double-bounded and single-bounded, would lead to a different conclusion.

We also looked at the internal income effect in the analyses studies, and based on a logit model of internal income significance, found that increasing income levels causes decreasing significance of internal income effect on WTP (Table 5). Income level and inequality, e.g. measured by the Gini coefficient, is normally not found to correlate closely (e.g. IMF 2007b), so the explanation should probably more be found in the regressive elasticity between studies - that WTP constitutes a smaller proportion of income in rich countries/respondent groups and consequently differences means relatively less to rich respondents. 
In the reported models we used a panel-structure for estimates derived from the same studies, in order to allow for differences caused by unobserved factors within studies which are not explained by the explanatory variables used to distinguish variation across studies (that is, which allows for error correlation within studies). This turned out to provide results which were quite different from models based on pooling all estimates and ignoring the panel structure of the data. An averaging procedure for estimates with the same characteristics provided somewhat similar results, but still a panel structure could not be rejected. Consequently, we believe potential strata have to be considered and tested before performing meta-studies. Bateman and Jones (2003) have suggested an alternative approach to dealing with the hierarchical nature of meta analysis data, which they refer to as multi-level modelling. We acknowledge that this appears to be a useful alternative to panel data approaches in future work.

\section{Concluding remarks}

This paper describes a meta-analysis which considers the variation in WTP for a wide variety of environmental goods brought together under the descriptor of "biodiversity conservation". All other things being equal, this widely-spread net results in a large inherent variation in WTP, which is likely to be mainly due to unobserved factors such as institutional setting, environmental attitudes and biodiversity context. Many of our parameter estimates in the "full model" are insignificant and the $\mathrm{R}^{2}$ of all our models is relatively low. However, the study makes a contribution exactly because of this broad inclusion. We are able to show that, across countries and habitats, there seems to be a significant effect of wealth on WTP for species and habitat conservation, and that this effect is as well-measured using GDP per capita as self-reported income. As we explain above, there are consistency problems with using self-reported income from CV studies to explain the income 
elasticity of WTP, yet this is the main way in which previous studies have sought to do this (e.g Poe et al, 2001; Brander et al. (2006) being an exeption by using GDP).

Our main result is that rising income increases peoples' WTP for nature conservation. This might be important for nature conservation plans with long time horizons, as it indicates that as societies become richer, they tend to value biodiversity more highly. Benefits in present value terms can thus be expected to rise over time, independently of any scarcity-induced increase in values. This is a point first made conceptually by Krutilla and Fisher (1975), but now it appears that there is good empirical evidence to back up this claim. However, the income elasticity of WTP for biodiversity conservation is less than unity: environmental protection, on this evidence, is not progressively distributed, despite willingness to pay rising with economic well-being.

\section{Acknowledgements}

We would like to thank the authors of the studies included who have provided us with information not given in published papers, even when they had to dig it out from quite old material. We also thank participants at the 2007 European Association of Environmental and Resource Economists conference, Henrik Lindhjem and two anonymous reviewers for comments on an earlier version. Jette Bredahl Jacobsen would also like to thank the Danish Research Council who financed part of this study. 


\section{Appendix 1. Studies included in the meta-analysis.}

\begin{tabular}{|c|c|c|c|c|c|c|}
\hline Reference & \begin{tabular}{|l|} 
Year \\
of \\
stud \\
$\mathrm{y}$ \\
\end{tabular} & Population & What is valued & \begin{tabular}{|l|} 
Habitat \\
preservation
\end{tabular} & $\begin{array}{l}\text { Species } \\
\text { preservation }\end{array}$ & $\begin{array}{l}\text { \# of used } \\
\text { estimates }\end{array}$ \\
\hline Amigues et al., 2002 & 2000 & $\begin{array}{l}\text { Toulouse metropolitan area, south- } \\
\text { central France }\end{array}$ & Wetlands /Riparian forests along rivers & yes & no & 6 \\
\hline Amirnejad et al., 2006 & 2004 & Iran & Preservation of forest & yes & no & 1 \\
\hline $\begin{array}{l}\text { Bandara \& Tisdell, } \\
2004\end{array}$ & 2001 & Colombo, Sri Lanka & Asian Elephant & no & yes & 3 \\
\hline $\begin{array}{l}\text { Bateman \& Langford, } \\
1997\end{array}$ & 1991 & Great Britain & Conserving broads in present state, freshwater wetland & yes & no & 1 \\
\hline Bergstrom et al., 1985 & \begin{tabular}{|l|}
1981 \\
-82 \\
\end{tabular} & Greenville County, South Carolina, USA & Agricultural land & yes & no & 1 \\
\hline Boiesen et al., 2005 & 2004 & Denmark & Heathland preservation & yes & yes & 4 \\
\hline Bowker \& Stoll, 1988 & 1983 & Texas to Alaska, USA & Whopping crane & no & yes & 12 \\
\hline $\begin{array}{l}\text { Cameron \& Quiggin } \\
1994 \text { revised } 1998 \text { \& } \\
\text { Carson et al., } 1994\end{array}$ & $\begin{array}{ll}1990 / \\
1991\end{array}$ & $\begin{array}{l}\text { Kakadu region, Northern Territory, } \\
\text { Australia }\end{array}$ & National park (as opposed to mining) & yes & no & 2 \\
\hline Chang \& Ying, 2005 & 2001 & Taiwan & $\begin{array}{l}\text { Programme to sustain agricultural areas, (incl. water and } \\
\text { habitat preservation) }\end{array}$ & yes & no & 2 \\
\hline Franco et al, 2001 & 1999 & Venice Municipality, Italy & Establishment of agroforestry networks & yes & no & 1 \\
\hline Giraud et al., 1999 & 1995 & $\begin{array}{l}\text { Southern Utah, Southeastern Colorado, } \\
\text { Western New Mexico, Arizona and the } \\
\text { whole USA in a separate sample } \\
\end{array}$ & Mexican spotted owl & no & yes & 2 \\
\hline Giraud et al., 2002 & 2000 & Alaskan Borough, USA & Expansion of Federal Steller Sea Lion recovery program & no & yes & 3 \\
\hline Gong, 2003 & 2001 & China & Programme for biodiversity conservation in Nature Reserve & no & yes & 2 \\
\hline Hadker et al., 1997 & 1995 & Bombay, India & National park & yes & no & 1 \\
\hline Hailu et al., 2000 & 1995 & Alberta, Canada & Conservation programme old growth forest & yes & yes & 3 \\
\hline Hammitt et al., 2001 & 1993 & \begin{tabular}{|l|l} 
Taiwan \\
\end{tabular} & Preservation of wetland & yes & no & 2 \\
\hline Heberlein et al., 2005 & 1998 & $\begin{array}{l}\text { Vilas ad Oneida Counties, Northern } \\
\text { Wisconsin, USA }\end{array}$ & Water quality, all lakes in county & yes/no & yes/no & 3 \\
\hline Holmes et al., 2004 & 2000 & Macon County,North Carolina, USA & Restoration of riparian area & yes & yes/no & 8 \\
\hline Jacobsen et al., 2006 & 2005 & A number of counties, Denmark & National park & yes & no & 7 \\
\hline $\begin{array}{l}\text { Jakobsson \& Dragun, } \\
2001 \text { and } 1996\end{array}$ & 1988 & State of Victoria, Australia & Conservation of endangered species & no & yes & 3 \\
\hline Kwak et al., 2003 & 2001 & Seoul Metropolitan area, Korea & Urban forest, amenity values & yes & yes & 1 \\
\hline Lehtonen et al., 2003 & 2002 & Finland & Forest conservation programme & yes & no & 1 \\
\hline León, 1996 & 1993 & Gran Canaria, Spain & Group of national parks & yes & no & 4 \\
\hline $\begin{array}{l}\text { Lockwood \& Carberry, } \\
1998\end{array}$ & 1997 & New South Wales, Australia & Preservation of reminant native vegetation & yes & no & 2 \\
\hline $\begin{array}{l}\text { Loomis \& Gonzales- } \\
\text { Caban, } 1998\end{array}$ & 1995 & California and New England, USA & Protection of old growth forest as habitat for spotted owl & yes & yes & 1 \\
\hline
\end{tabular}




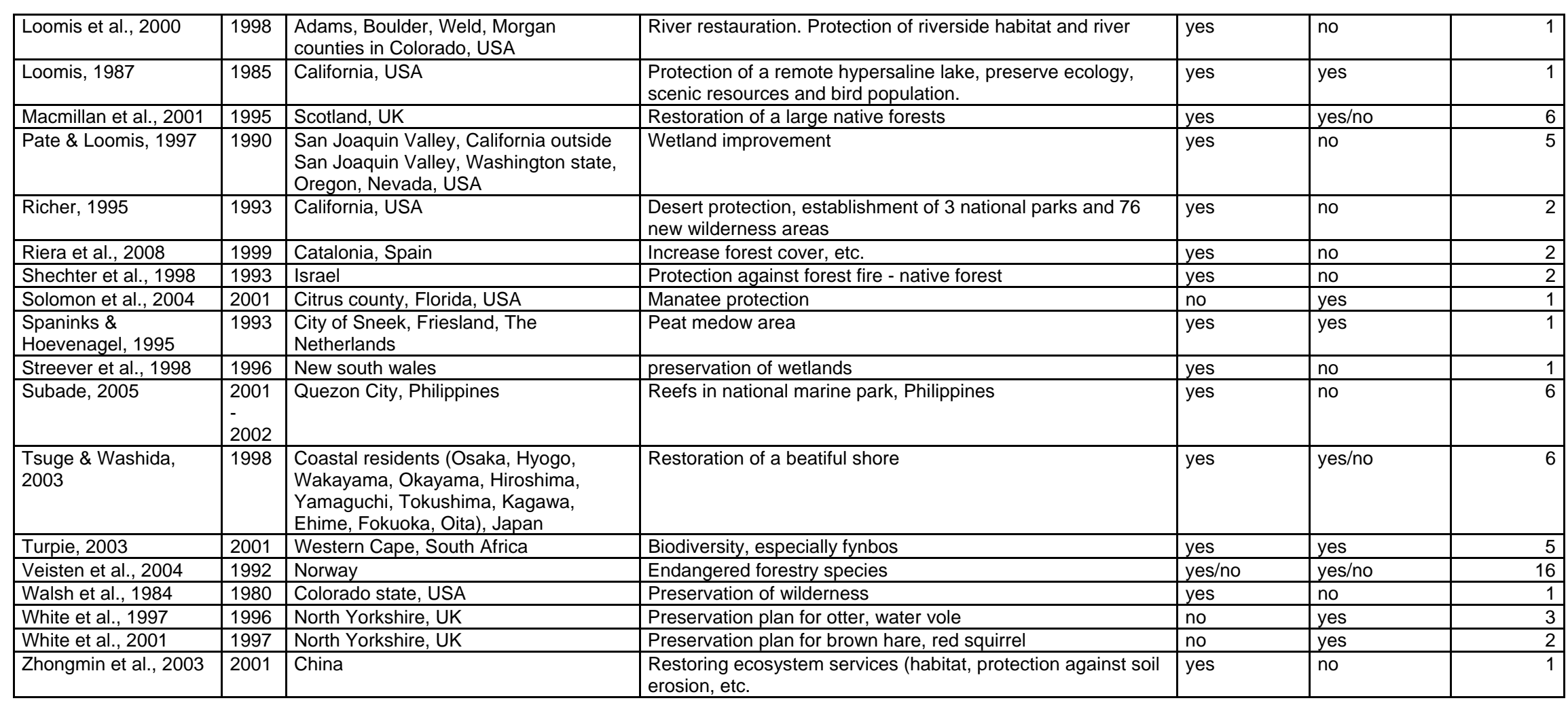




\section{References}

Amigues, J. P., C. Boulatoff, B. Desaigues, C. Gauthier and J. E. Keith (2002), 'The benefits and costs of riparian analysis habitat preservation: a willingness to accept/willingness to pay contingent valuation approach', Ecological Economics 43, 17-31.

Armirnejad, H., S. Khalilian, M.H., Assareh and M. Ahmadian (2006), 'Estimating the existence value of north forests of Iran by using a contingent valuation method', Ecological Economics $58,665-675$.

Bal, F., K. J. Button and P. Nijkamp (2002), 'Ceteris paribus, meta-analysis and the value transfer', Socio-Economic Planning Sciences 36, 127-138.

Bandera, R. and C. Tisdell (2004), 'The net benefit of saving the Asian elephant: a policy and contingent valuation study', Ecological Economics 48, 93-107.

Barbier, E. B. (1997), 'Introduction to the environmental Kuznets curve'. Environment and Development Economics 2, 369-381.

Bateman, I. J. and I. H. Langford (1997), 'Non-users' Willingness to Pay for a National Park: An Application and critique of the Contingent Valuation Method', Regional Studies 31, 571-582.

Bateman, I. J., I. H. Langford, R. K. Turner K. G. Willis and G. D. Garrod (1995), 'Elicitation and truncation effects in contingent valuation studies', Ecological Economics 12, 161-179.

Bateman I. J. and J. Mawby (2004), 'First impressions count: interviewer appearance and information effects in stated preference studies', Ecological Economics 49, 47-55 
Bateman I.J. and Jones A.P. (2003) “Contrasting conventional with multi-level modelling approaches to meta-analysis: expectation consistency in UK woodland recreation values" Land Economics, 79 (2), 235-258.

Bennett, J.W. (1984), 'Using direct questioning to value the existence benefits of preserved natural areas', Australian Journal of Agricultural Economics 28, 136-152.

Bergstrom, J. C., B. L. Dillman and J. R. Stoll (1985), 'Public Environmental Amenity Benefits of Private Land: The Case of Prime Agricultural Land', Southern Journal of Agricultural Economics July, 139-149.

Boiesen, J. H., J.B. Jacobsen, B.J. Thorsen, N. Strange and A. Dubgaard (2005), Vaerdiscetning af de danske lyngheder [Valuation of Danish heathland], Working paper 14, Forest \& Landscape, $68 \mathrm{pp}$.

Bowker, J. M. and J. R. Stoll (1988), 'Use of dichotomous choice nonmarket methods to value the whooping crane resource', American Journal of Agricultural Economics 70, 372-381.

Boxall, P. C., W. L Adamowicz, J. Swait, M. Williams.and J. Louviere (1996), 'A comparison of stated preference methods for environmental valuation', Ecological Economics 18, 243-253.

Brander, L. M., P. Van Beukering, S. J. C. Herman (2007), 'The recreational value of coral reefs: A meta-analysis', Ecological Economics 63, 209-218

Brander, L. M., R. J. G. M. Florax, J. E. Vermaat (2006), 'The Empirics of Wetland Valuation: A Comprehensive Summary and a Meta-Analysis of the Literature', Environmental and Resource Economics 33, 223-250 
Brouwer, R. and I. Bateman (2001), 'The temporal stability of contingent WTP values' Proceedings from EEARE $11^{\text {th }}$ annual conference, University of Southampton, UK. 28-30 June 2001.

Brouwer, R., I. H. Langford, I. J. Bateman and R. K. Turner (1999), ‘A meta-analysis of wetland contingent valuation studies', Regional Environmental Change 1, 47-57

Bruvall A., T. Faehn and B. Strom (2003) "Quantifying central hypotheses on Environmental Kuznets Curves for a rich economy” Scottish Journal of Political Economy, 50 (2), 149-173.

Cameron, T. A. and J. Quiggin (1994), 'Estimation Using Contingent Valuation Data from a "Dichotomous Choice with Follow-Up" Questionnaire', Journal of Environmental Economics and Management 27, 218-234.

Cameron, T. A. and J. Quiggin (1998), 'Estimation Using Contingent Valuation Data from a "Dichotomous Choice with Follow-Up" Questionnaire: Reply', Journal of Environmental Economics and Management 35, 195-199.

Carson, R. T., L. Wilks, and D. Imber (1994), 'Valuing the preservation of Australia's Kakadu conservation zone', Oxford Economic Papers 46, 727-749.

Chang, K. and Y. H. Ying (2005), 'External benefits of preserving agricultural land: Taiwan's rice fields', Social Science Journal 42, 285-293.

Christie, M., N. Hanley, J. Warren, K. Murphy, R. Wright and T. Hyde (2006), 'Valuing diversity of biodiversity', Ecological Economics 58, 304-317.

Deacon R. T. and C. S. Norman (2006) "Does the Environmental Kuznets Curve describe how countries behave?" Land Economics 82 (2), 291-315. 
Ebert, U. (2003) "Environmental goods and the distribution of income" Environmental and Resource Economics, 25, 435-459.

Franco, D., D. Franco, I. Mannino and G. Zanetto (2001), 'The role of agroforestry networks in landscape socioeconomic processes: the potential and limits of the contingent valuation method', Landscape and Urban Planning 55, 239-256.

Garcia-Lopez, G. (2006) 'Evaluating the validity of the Benefit Transfer approach: The case of manatee protection in Florida and Puerto Rico.' Masters thesis, Department of Land Economy, Cambridge University.

Ghani, A. N. A. (2006), 'Application of Total Economic Valuation Methods to Ayer Hitam Forest Reserve, Puchong', Unpubl.

Giraud, K. L., J. B. Loomis and R. L. Johnson (1999), 'Internal and external scope in willingnessto-pay estimates for threatened and endangered wildlife', Journal of Environmental Management 56, 221-229.

Giraud, K., B. Turcin, J. Loomis, J. Cooper (2002), 'Economic benefit of the protection program for the Steller sea lion', Marine Policy 26, 451-458.

Gong, Y. (2003), 'Opportunity cost of local people and WTP of off-site residents for biodiversity conservation in Fanjingshan National Nature Reserve in China', CCAP Working Paper 04-E1, $39 \mathrm{pp}$.

Greene, W. H. (2002), 'Econometric Analysis', Fifth Edition, Prentice Hall, New Jersey, 1026 pp.

Grossman, G. M. and A. B. Krueger (1995), 'Economic growth and the environment', The Quarterly Journal of Economics 110, 353-377. 
Hadker, N., S. Sharma, A. David and T. R. Muraleedharan (1997), 'Willingness-to-pay for Borivli National Park: evidence from a Contingent Valuation', Ecological Economics 21, 105-122.

Hailu, A., W. L. Adamowicz, P. C. Boxall (2000), 'Complements, Substitutes, Budget Constraints and Valuation', Environmental and Resource Economics 16, 51-58.

Hammitt, J., J.-T. Liu, J.-L. Liu (2001), 'Contingent valuation of a Taiwanese wetland', Environment and Development Economics 6, 259-268.

Hanley, N., D. Macmillan, R.E. Wright, C. Bullock, I. Simpson, D. Parsisson and B. Crabtree (1998a), 'Contingent Valuation versus Choice Experiments: Estimating the Benefits of Environmentally Sensitive Areas in Scotland', Journal of Agricultural Economics 49, 1-15.

Hanley, N., R. E. Wright and V. Adamowicz (1998b), 'Using Choice Experiments to Value the Environment', Environmental and Resource Economics 11, 413-428.

Hanley, N., D. Macmillan, I. Patterson and R. E. Wright (2003), 'Economics and the design of nature conservation policy: a case study of wild goose conservation in Scotland using choice experiments', Animal Conservation 6, 123-129.

Heberlein, T. A., M. A. Matthew, R. C. Bishop and N. C. Schaeffer (2005), 'Rethinking the scope test as a criterion for validity in contingent valuation', Journal of Environmental Economics and Management 50, 1-22.

Hökby, S. and T. Söderqvist (2003), 'Elasticities of Demand and Willingness to Pay for Environmental Services in Sweden', Environmental and Resource Economics 26, 361-383. 
Holmes, T. P., J.C. Bergstrom, E. Huszar, S. B. Kask and F. Orr (2004),' Contingent valuation, net marginal benefits, and the scale of riparian ecosystem restoration', Ecological Economics 49, 19-30.

Hunter, J. E. and F. L. Schmidt (2004), 'Methods of Meta-Analysis, Correcting Error and Bias in Research Findings', Second edition SAGE Publications, London, 582 pp.

IMF (2007a), World Economic Outlook Database. September 2006 Edition. Downloaded from http://www.imf.org/external/pubs/ft/weo/2006/02/data/download.aspx on 5 January 2007.

IMF (2007b), World Economic Outlook, October 2007, Globalization and Inequality, International Monetary Fund, Washington, 275 pp.

Jacobsen, J.B., B.J. Thorsen, J. H. Boiesen, S. Anthon and J. Tranberg (2006), 'Værdisætning af syv mulige nationalparker i Danmark’ [Valuation of seven potential national parks in Denmark], Summary in English, Arbejdsrapport 28, Forest \& Landscape, KVL, Frederiksberg. $63 \mathrm{pp}$.

Jacobsen, J.B. and B. J. Thorsen (2008), 'Where to put a national park and what to put in it? An a priori study of the willingness-to-pay for coming national parks'. Working paper.

Jakobsson, K. M and A. K. Dragun (1996), Contingent Valuation and Endangered Species. Methodological Issues and Applications. Edward Elgar, Cheltenham, UK. 269 pp.

Jakobsson, K. M. and A. K. Dragun (2001), 'The Worth of a Possom: Valuing Species with the Contingent Valuation Method', Environmental and Resource Economics 19, 211-227.

Johnson, R. L., N. S. Bregenzer and B. Shelby (1990), 'Contingent Valuation Question Formats: Dichotomous Choice versus Open-Ended Responses'. In: Economic Valuation of Natural 
Resources. Issues, Theory and Applications. Eds.: Johnson, R. L., G. V. Johnson. Pp 193-204. Social Behaviour and Natural Resource Series. Westview Press, Boulder, Colorado, USA. 220 pp.

Kriström, B. and P. Riera (1996), 'Is the Income Elasticity of Environmental Improvements Less Than One?', Environmental and Resource Economics 7, 45-55.

Krutilla J.V. and A. C. Fisher (1975) 'The Economics of Natural Environments. Studies in the Valuation of Commodity and amenity resources', Resources for the future, Washington DC, Colorado, USA.

Kuznets (1955), 'Economic growth and income inequality', The American Economic Review 49, 128

Kwak, S.-J., S.-H. Yoo and S.-Y. Han (2003), 'Estimating the Public's Value for Urban Forest in the Seoul Metropolitan Area of Korea: A Contingent Valuation Study', Urban Studies 40, 2207-2221.

Lehtonen, E., J. Kuulivainen, E. Pouta, M. Rekola and L. Chian-Zhong (2003), 'Non-market benefits of forest conservation in southern Finland', Environmental Science and Policy 6, 195204.

León, C. J. (1996), ‘Double bounded survival values for preserving the landscape of natural parks’ Journal of Environmental Management 46, 103-118.

Lindhjem, H. (2007), '20 years of Stated Preference Valuation of Non-Timber Benefits from Fennoscandian Forests: A Meta-Analysis', Journal of Forest Economics 12, 251-277 
Lockwood, M. and D. Carberry (1998), 'Stated Preference Surveys of Remnant Native Vegetation Conservation' Johnstone Centre Report No. 104, Albury, 30 pp.

Loomis, J. B. (1987), 'Expanding Contingent Value Sample Estimates to Aggregate Benefit Estimates: Current Practices and Proposed Solutions', Land Economics 63, 396-402.

Loomis, J. B. and A. Gonzales-Caban (1998), 'A willingness-to-pay function for protecting acres of spotted owl habitat from fire', Ecological Economics 25, 315-322.

Loomis, J., M. Lockwood and T. DeLacy (1993), 'Some Empirical Evidence on Embedding Effects in Contingent Valuation of Forest Protection', Journal of Environmental Economics and Management 24, 45-55.

Loomis, J. B. and D. S. White (1996), 'Economic benefits of rare and endangered species: summary and meta-analysis', Ecological Economics 18, 197-206.

Loomis, J. B., P. Kent, L. Strange, K. Fausch and A. Covich (2000), 'Measuring the total economic value of restoring ecosystem services in an impaired river basin: results from a contingent valuation survey', Ecological Economics 33, 103-117.

Macmillan, D. C., E. I. Duff and D. A. Elston (2001), 'Modelling the non-market environmental costs and benefits of biodiversity projects using contingent valuation data', Environmental and Resource Economics 18, 391-410.

McPherson M.A. and M. L. Nieswiadomy (2005) 'Environmental Kuznets Curve: threatened species and spatial effects' Ecological Economics 55, 395-407.

Metrick, A. and M. L. Weitzman (1994), 'Patterns of behavior in biodiversity preservation', The World Bank Policy Research Working Paper 1358, 36 pp. 
Mitchell, R. C. and R. T. Carson (1989), Using surveys to value public goods, The contingent valuation method, Resources for the Future, Washington DC, $463 \mathrm{pp}$

Munro, A., 2005: Household willingness to pay equals individual willingness to pay if and only if the household income pools. Economics Letters 88: 227-230.

Pang, F., M. Drummond, F. Song (1999), 'The use of meta-analysis in economic valuation', Discussion Paper 173, Centre for Health Economics, The University of York, 25 pp.

Pate, J. and L. Loomis (1997), 'The effect of distance on willingness to pay values: A case study of wetlands and salmon in California', Ecological Economics 20, 199-207.

Poe, G. L., K. J. Boyle and J. C. Bergstrom (2000), ‘A meta analysis of contingent values for groundwater quality in the United States', $10^{\text {th }}$ Annual Conference of the European Association of environmental and Resource Economists, 30 June - 2 July, University of Crete, Greece.

Reaves, D. W., R. A. Kramer and T. P. Holmes (1999), 'Does question format matter? Valuing endangeres species', Environmental and Resource Economics 14, 365-383.

Richer, J. (1995), 'Willingness to pay for desert protection', Contemporary Economic Policy 13, 93-104.

Riera, P., J. Mogas and J. Bennett (2008), Forest value inference using contingent valuation and choice experiments. In: Birol, E. and P. Koundouri (Eds.). Choice Experiments Informing European Environmental Policy. Edward-Elgar Publishing, Wally Oates and Henk Folmer's 'New Horizons in Environmental Economics' Series, Cheltenham, UK. Forthcoming 
Rosenberger, R. S. and J. B. Loomis (2000), 'Panel Stratification in Meta-Analysis of Economic Studies: An Investigation of Its Effects in the Recreation Valuation Literature', Journal of Agricultural and Applied Economics 32, 459-470.

Shechter, M., B. Reiser and N. Zaitsev (1998), 'Measuring Passive Use Value, Pledges, Donations and CV Responses in Connection with an Important Natural Resource', Environmental and Resource Economics 12, 457-478.

Schläpfer, F. (2006), 'Survey protocol and income effects in the contingent valuation of public goods: A meta-analysis', Ecological Economics 57, 415-429.

Smith, V. K. and Y. Kaoru (1990), 'Signals or Noise? Explaining the Variation in Recreation Benefit Estimates', American Journal of Agricultural Economics 72, 419-433.

Smith, V. K. and L. L. Osborne (1996), ‘Do Contingent Valuation Estimates Pass a “Scope” Test? A Meta-analysis', Journal of Environmental Economics and Management 31, 287-301.

Smith, V. K. and K. Pattanayak (2002), 'Is Meta-Analysis a Noah’s Ark for Non-Market Valuation?', Environmental and Resource Economics 22, 271-296

Solomon, B. D., C. M. Corey-Luse and K. E. Halvorsen (2004), 'The Florida manatee and ecotourism: toward a safe minimum standard', Ecological Economics 50, 101-115.

Spanniks, F. and R. Hoevenagel (1995), 'Temporal Embedding in Contingent Valuation: Evidence from a Study Investigating the Value of Wildlife Management in Agricultural Areas' Proceedings from the Sixth Annual Conference of the European Association of Environmental and Resource Economists, Umeå, Sweden, June 18-20, 1995. 
Streever, W. J., M. Callaghan-Perry, A. Searles, T. Stevens and P. Svoboda (1998), 'Public attitudes and values for wetland conservation in New South Wales, Australia', Journal of Environmental Management 54, 1-14.

Subade, R. F. (2005), 'Valuing Biodiversity Conservation in a World Heritage Site. Citizens Nonuse BValues for Tubbataha Reefs National Marine Park, Philippines', Economy and Environmental Program for Southeast Asia, Research Report No. 2005-RP4, 68 pp.

Tsuge, T. and T. Washida (2003), 'Economic valuation of the Seto Inland Sea by using an Internet CV survey', Marine Pollution Bulletin 47, 230-236.

Turpie, J. K. (2003), 'The existence value of biodiversity in South Africa: how interest, experience, knowledge, income and perceived level of threat influence local willingness to pay', Ecological Economics 46, 199-216.

van den Bergh, J., K. J. Button, P. Nijkamp and G. C. Pepping (1997), 'Meta-analysis in environmental economics', Economy \& Environment, Kluwer Academic Publishers, 240 pp.

Veisten, K., H. F. Hoen, S. Navrud and J. Strand (2004), 'Scope insensitivity in contingent valuation of complex environmental amenities', Journal of Environmental Management 73, $317-331$.

Walsh, R. G., J. B. Loomis and R. A. Gillman (1984), 'Valuing Option, Existence, and Bequest Demands for Wilderness', Land Economics 60, 14-29.

Welsh, M. P. and G. L. Poe (1998), 'Elicitation effects in contingent valuation: Comparisons to a multiple bounded discrete choice approach', Journal of Environmental Economics and Management 36, 170-185. 
White, P. C. L., K. W. Gregory, P. J. Lindley and G. Richards (1997), 'Economic values of threatened mammals in Britain: A case study of the otter Lutra lutra and the water vole Arvicola terrestris', Biological Conservation 82, 345-354.

White, P. C. L., A. C. Bennett and E. J. V. Hayes (2001), 'The use of willingness-to-pay approaches in mammal conservation' Mammal Review 31, 151-167.

Woodward, R. T. and Y.-S. Wui (2001), 'The economic value of wetland services: a meta-analysis', Ecological Economics 37, 257-270

Zhongmin, X., C. Guodong, Z. Zhiqiang, S. Zhiyong, J. Loomis (2003), ‘Applying contingent valuation in China to measure the total economic value of restoring ecosystem services in Ejina region', Ecological Economics 44, 345-358. 


\section{Figure legend}

Figure 1. WTP as a function of gross income (household or personal). Black dots are income measure per household and squares are income measures per person. A linear regression line is shown for interest. 
Table 1. Some statistics on the origin of 46 valuation studies, reporting 145 WTP estimates.

Time span: 1979-2005

\section{Study origin}

Africa

5

Asia

26

Australia

14

Europe

54

North America

44

South America

2

Focus of study ${ }^{1}$

Habitat preservation

95

Species preservation

75

Payment unit

Per household

Per person

34

Unspecified

1

Income unit

Per household

Per person

Unspecified

3

Payment interval

One-time $^{2}$

Per year 
Monthly ${ }^{3}$

Unspecified

\section{Payment vehicle}

$\begin{array}{ll}\text { Tax } & 68\end{array}$

Donation 38

Use charges $^{4} \quad 17$

Free choice $^{5} \quad 14$

$\operatorname{Mix}^{6}$

Unspecified 3

Questionnaire Format

Dichotomous choice $\quad 92$

Open ended 53

\section{Data collection}

$\begin{array}{ll}\text { Postal questionnaire } & 67\end{array}$

Face-to-face $\quad 47$

Telephone interview 15

Electronic questionnaire $\quad 14$

Unspecified 2

Time of survey

$\begin{array}{ll}1979-1989 & 19\end{array}$

1990-1999 72

2000-2005 54

${ }^{1}$ Sometimes overlapping 
${ }^{2}$ One-time payments are not converted to annual payments as it requires extra assumptions on interest rate and duration and would thus result in variation caused by the treatment of data, not the data itself. Instead we have included a dummy variable for the payment interval in the analysis.

${ }^{3}$ Multiplied by 12 to obtain annual payments in the estimations

${ }^{4}$ E.g. water bills

${ }^{5}$ E.g. What was considered right by the respondent

${ }^{6}$ E.g. half tax, half donation 
Table 2. List of variables used as explanatory variables

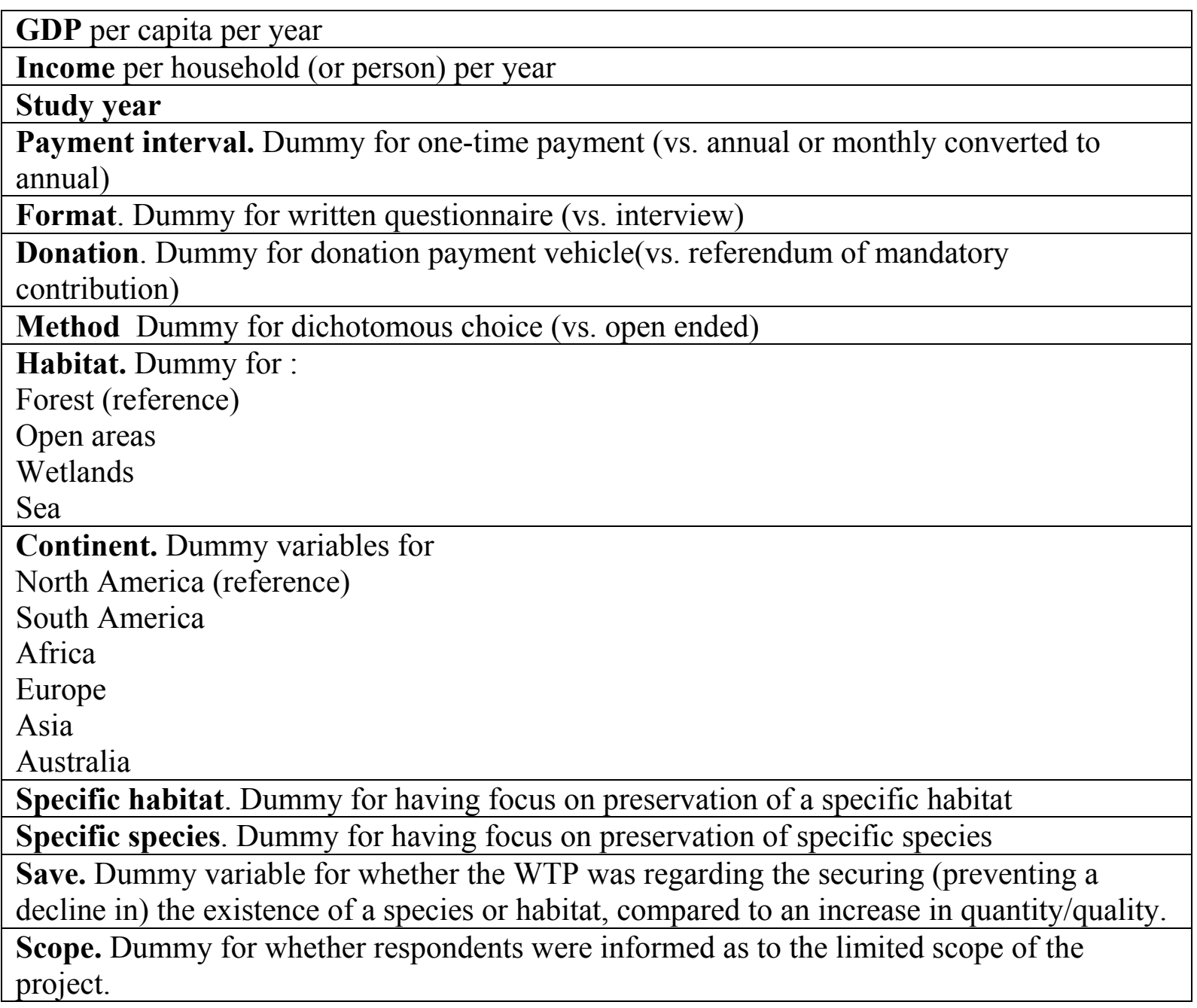


Table 3: Estimation results for models based on income or GDP per capita alone.

\begin{tabular}{lrrrr}
\hline Semi-log (income) & Coefficient & Stand.Err. & $\mathbf{Z}$ & $\mathbf{P}>|\mathbf{z}|$ \\
log(income) & 21.96 & 7.90 & 2.78 & 0.005 \\
Constant & -145.39 & 75.16 & -1.93 & 0.053 \\
Wald X2 & 7.73 & & $\mathbf{R}^{2}$ (within) & 0.0191 \\
P>X2 & 0.0054 & & $\mathbf{R}^{2}$ (between) & 0.0427 \\
$\mathbf{N}$ & 128 & & $\mathbf{R}^{2}$ (overall) & 0.0195 \\
\hline Doublelog (income) & Coefficient & Stand.Err. & $\mathbf{z}$ & $\mathbf{P}>|\mathbf{z}|$ \\
log(income) & 0.38 & 0.14 & 2.67 & 0.01 \\
Constant & -0.08 & 1.43 & -0.05 & 0.96 \\
Wald X2 & 7.13 & & $\mathbf{R}^{2}$ (within) & 0.0548 \\
P>x2 & 0.0076 & & $\mathbf{R}^{2}$ (between) & 0.0336 \\
$\mathbf{N}$ & 127 & & $\mathbf{R}^{2}$ (overall) & 0.0199 \\
\hline Semi-log (GDP) & Coefficient & Stand.Err. & $\mathbf{z}$ & $\mathbf{P}>|\mathbf{z}|$ \\
log(GDP) & 29.12 & 12.82 & 2.27 & 0.02 \\
Constant & -208.16 & 120.38 & -1.73 & 0.08 \\
WaldX2 & 5.16 & & $\mathbf{R}^{2}$ (within) & 0.0000 \\
P>x2 & 0.0232 & & $\mathbf{R}^{2}$ (between) & 0.0639 \\
$\mathbf{N}$ & 111 & & $\mathbf{R}^{2}$ (overall) & 0.0225 \\
\hline Doublelog (GDP) & Coefficient & Stand.Err. & $\mathbf{z}$ & $\mathbf{P}>|\mathbf{z}|$ \\
log(GDP) & 0.38 & 0.22 & 1.68 & 0.09 \\
Constant & 0.09 & 2.21 & 0.04 & 0.97 \\
Wald X2 & 2.84 & & $\mathbf{R}^{2}$ (within) & 0.0000 \\
P>x2 & 0.0922 & & $\mathbf{R}^{2}$ (between) & 0.0519 \\
$\mathbf{N}$ & 110 & & $\mathbf{R}^{2}$ (overall) & 0.009 \\
\hline
\end{tabular}

* significant at the $95 \%$-level, ${ }^{* *}$ at the $99 \%$-level, $* * *$ at the pp. $9 \%$-level and NS not significant 
Table 4a. Estimation results for random effects panel models for income or GDP per capita with all study design variables included. Dependent variable is WTP.

\begin{tabular}{|c|c|c|c|c|c|c|c|c|c|c|}
\hline & \multicolumn{4}{|c|}{$\begin{array}{l}\text { Income model } \\
\text { Stand. }\end{array}$} & \multicolumn{4}{|c|}{$\begin{array}{l}\text { GDP per capita model } \\
\text { Stand. }\end{array}$} & \multicolumn{2}{|c|}{ Correlation with: } \\
\hline & Coefficient & Err. & $\mathbf{z}$ & $P>|z|$ & Coefficient & Err. & $\mathbf{z}$ & $P>|z|$ & income & GDP \\
\hline $\begin{array}{l}\text { log(income or } \\
\text { GDP) }\end{array}$ & 15.61 & 14.93 & 1.05 & 0.296 & 34.41 & 31.05 & 1.11 & 0.268 & 1 & 1 \\
\hline Studyyear & 0.87 & 2.98 & 0.29 & 0.771 & 0.48 & 3.66 & 0.13 & 0.896 & 0.2787 & 0.0156 \\
\hline specific species & -12.29 & 24.33 & -0.51 & 0.613 & -12.60 & 24.13 & -0.52 & 0.602 & -0.1707 & -0.107 \\
\hline specific habitat & 87.24 & 44.72 & 1.95 & 0.051 & 83.14 & 48.25 & 1.72 & 0.085 & -0.1855 & -0.2945 \\
\hline save & 1.76 & 39.45 & 0.04 & 0.964 & -2.89 & 38.60 & -0.07 & 0.94 & 0.1827 & -0.1311 \\
\hline scope & 10.55 & 12.26 & 0.86 & 0.39 & 8.52 & 12.68 & 0.67 & 0.501 & -0.1637 & -0.0462 \\
\hline donation & 31.40 & 44.12 & 0.71 & 0.477 & 58.87 & 50.37 & 1.17 & 0.243 & -0.1315 & -0.2825 \\
\hline method & 51.18 & 18.56 & 2.76 & 0.006 & 58.80 & 20.32 & 2.89 & 0.004 & 0.0065 & 0.1272 \\
\hline payment interval & 0.21 & 20.91 & 0.01 & 0.992 & -14.58 & 21.31 & -0.68 & 0.494 & 0.1632 & -0.2743 \\
\hline format & 0.21 & 41.85 & 0 & 0.996 & -16.88 & 45.78 & -0.37 & 0.712 & -0.2102 & -0.3128 \\
\hline South America & -47.23 & 87.22 & -0.54 & 0.588 & -111.51 & 89.67 & -1.24 & 0.214 & 0.0376 & -0.3677 \\
\hline Europe & -14.17 & 66.09 & -0.21 & 0.83 & -3.73 & 62.74 & -0.06 & 0.953 & -0.0828 & -0.2709 \\
\hline Asia & -54.85 & 62.86 & -0.87 & 0.383 & -48.51 & 64.48 & -0.75 & 0.452 & 0.1171 & 0.4151 \\
\hline Africa & -46.50 & 94.56 & -0.49 & 0.623 & -58.83 & 102.78 & -0.57 & 0.567 & 0.3207 & 0.2303 \\
\hline Australia & -59.97 & 49.74 & -1.21 & 0.228 & -61.01 & 48.63 & -1.25 & 0.21 & -0.0056 & 0.0229 \\
\hline Habitat: Sea & -21.28 & 29.75 & -0.72 & 0.474 & -24.28 & 30.56 & -0.79 & 0.427 & 0.0419 & 0.0876 \\
\hline Habitat: Wetlands & -25.19 & 25.30 & -1 & 0.319 & -27.77 & 26.67 & -1.04 & 0.298 & -0.2061 & -0.0223 \\
\hline Habitat: Open & -23.04 & 16.38 & -1.41 & 0.16 & -24.78 & 16.42 & -1.51 & 0.131 & -0.1461 & 0.061 \\
\hline Constant & -1879.40 & 5987.42 & -0.31 & 0.754 & -1281.95 & 7313.72 & -0.18 & 0.861 & -0.3004 & -0.0543 \\
\hline $\mathbf{N}$ & 124 & & & & 109 & & & & & \\
\hline Wald $x^{2} / \mathrm{P}>\mathrm{x}^{2}$ & 55.97 & $/ 0.000$ & & & 49.03 & $/ 0.000$ & & & & \\
\hline $\mathbf{R}^{2}$ (within) & 0.185 & & & & 0.171 & & & & & \\
\hline $\mathbf{R}^{2}$ (between) & 0.161 & & & & 0.221 & & & & & \\
\hline $\mathbf{R}^{2}$ (overall) & 0.098 & & & & 0.123 & & & & & \\
\hline$\sigma \mu$ & 97.18 & & & & 97.80 & & & & & \\
\hline$\sigma \varepsilon$ & 41.98 & & & & 45.09 & & & & & \\
\hline$\rho$ & 0.84 & & & & 0.82 & & & & & \\
\hline
\end{tabular}


Table 4b. Estimation results for the dependence of WTP on income or per capita GDP with only those study design variables significant at $95 \%$ or higher, random effects panel model. Dependent variable is WTP.

\begin{tabular}{|c|c|c|c|c|c|c|c|c|}
\hline & Coefficient & Stand.Err. & $\mathbf{z}$ & $P>\mid z$ & Coefficient & Stand.Err. & $\mathbf{z}$ & $P>\mid z$ \\
\hline log income & 16.95 & 10.17 & 1.67 & 0.09 & - & - & - & - \\
\hline $\begin{array}{l}\text { log GDP per } \\
\text { capita }\end{array}$ & - & - & - & - & 27.75 & 15.22 & 1.82 & 0.06 \\
\hline $\begin{array}{l}\text { Specific } \\
\text { habitat }\end{array}$ & 70.93 & 30.62 & 2.32 & 0.02 & 72.87 & 30.59 & 2.38 & 0.01 \\
\hline method & 45.84 & 17.64 & 2.60 & 0.00 & 45.49 & 18.46 & 2.46 & 0.01 \\
\hline constant & -176.84 & 96.46 & -1.83 & 0.06 & \begin{tabular}{|l|}
-278.77 \\
\end{tabular} & 147.71 & -1.89 & 0.06 \\
\hline $\mathrm{n}$ & 128 & & & & 111 & & & \\
\hline $\begin{array}{l}\text { Wald } \chi^{2 /} \\
\mathrm{P}>\chi^{2}\end{array}$ & $19.26 / 0.00$ & & & & $16.48 / 0.00$ & & & \\
\hline $\mathrm{R}^{2}$ (within) & 0.17 & & & & 0.16 & & & \\
\hline $\mathrm{R}^{2}$ (between) & 0.10 & & & & 0.12 & & & \\
\hline $\mathrm{R}^{2}$ (overall) & 0.08 & & & & 0.07 & & & \\
\hline$\sigma \mu$ & 72.73 & & & & 73.79 & & & \\
\hline$\sigma \varepsilon$ & 40.51 & & & & 43.54 & & & \\
\hline$\rho$ & 0.76 & & & & \begin{tabular}{|l|}
0.74 \\
\end{tabular} & & & \\
\hline
\end{tabular}


Table 5: Logit model of internal income significance at the 95\% level.

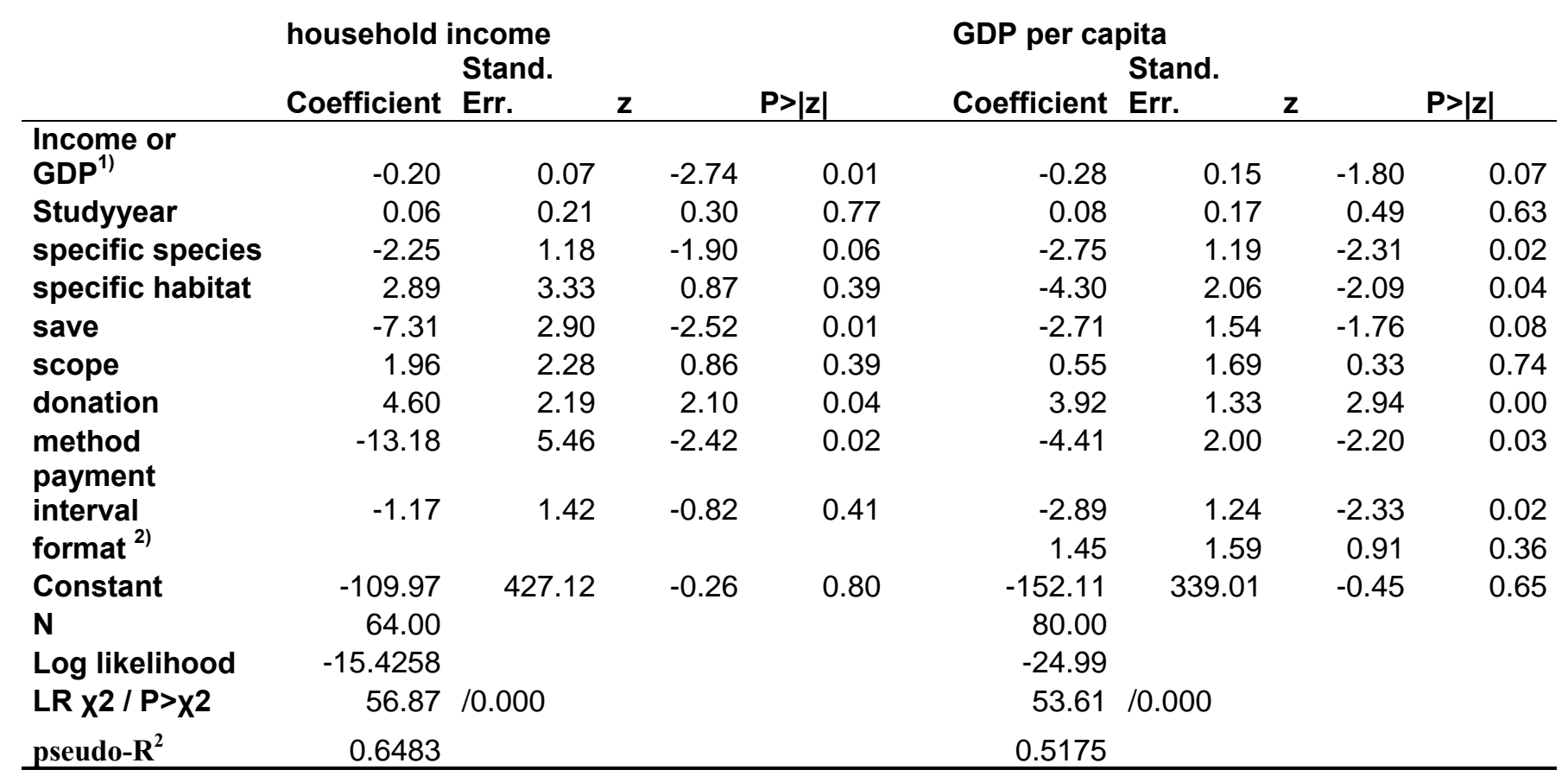

1) Income/1000 or GDP/1000

2) Format dropped in regression on income due to correlation problems if included 


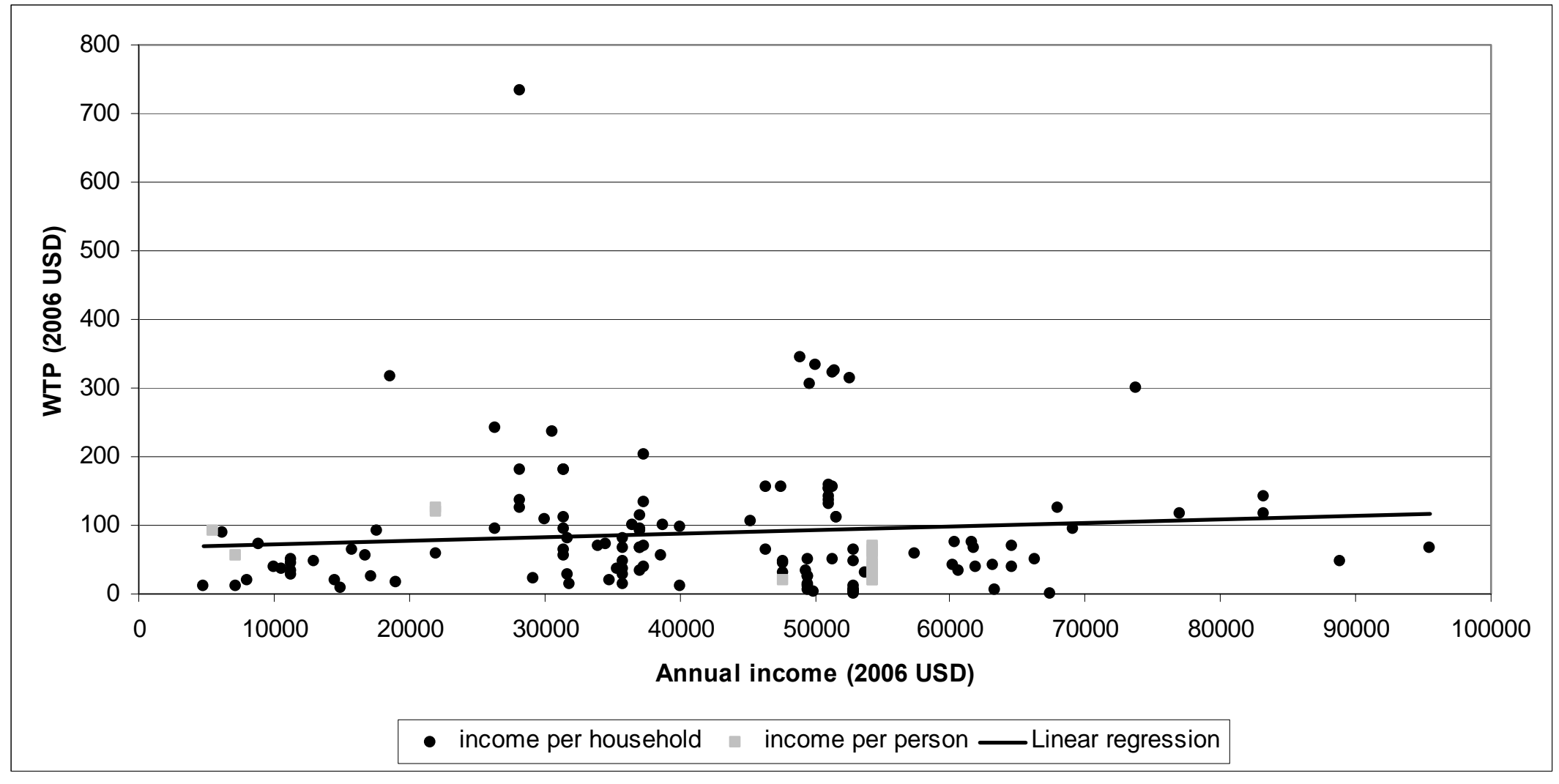

Figure 1.

WTP as a function of gross income (household or personal). Black dots are income measure per household and grey squares are income measures per person. A linear regression is shown. 